Vidulin, S. \& Kazić, S. (2021). Cognitive-emotional music listening paradigm in professional music education, International Journal of Cognitive Research in Science, Engineering and Education (IJCRSEE), 9(1), 135-145.

Review Article

UDK:

Received: January, 15.2021.

37.091.33-028.17-057.874

Revised: February, 18.2021.

$37.091 .33-027.22: 78.091$

Accepted: February, 28.2021.

doi: 10.23947/2334-8496-2021-9-1-135-145

\title{
Cognitive-Emotional Music Listening Paradigm in Professional Music Education
}

\author{
Sabina Vidulin ${ }^{1 *}$, Senad Kazić ${ }^{2}$ \\ 'University of Juraj Dobrila in Pula, Academy of Music in Pula, Croatia, e-mail: sabina.vidulin@unipu.hr \\ 2University of Sarajevo, Academy of Music in Sarajevo, Bosnia and Herzegovina, e-mail: senad.kazic@mas.unsa.ba
}

\begin{abstract}
Music education is an important factor of students' development. The positive effect of music training is evident in all areas, from the intellectual, psychomotor to social and emotional ones, and therefore music classes in the music school should focus both on music making and on experience, understanding and evaluating music, as well as on expressing one's own ideas, feelings and thoughts. In ear training classes it can be achieved through the area of music listening. Didactical initiatives of the 19th and 20th century contributed to the recognition of the advantages of the auditory approach, while technological innovations allowed the practical application of music listening. Although there are examples that point to fostering the emotional experience in music classes, music listening is still focused on giving assignments of cognitive type and learning about music components. Some exceptions pertain to the application of multimodality in music teaching using both musical and extra-musical areas. The paper is aimed at pointing to the value of the cognitive-emotional music listening and to the possibilities it opens in ear training classes. The cognitive-emotional music listening focuses on experiencing, understanding and appreciation of classical music aimed at shaping students' worldview and improving their music competences. It can be achieved by the multimodal and interdisciplinary approach to a musical piece. Students learn about the musical-historical context of the emergence of a piece in a given time and circumstances, about the composing approach and the theoretical and harmony features of the work, they develop their musical and critical thinking, make music, and evaluate both music and their own achievements. Repeated listening to a musical piece or excerpts from it, observing and familiarizing with the piece from different perspectives and discussion about the piece and experience after listening make it possible to better understand the piece and its specifics, as well as to discover and improve one's own self and accept others and the different.

Keywords: art education, cognitive-emotional music listening, ear training, music school.
\end{abstract}

\section{Introduction}

The education system of the countries that succeeded Yugoslavia preserved the same concept: primary, secondary and higher education. Besides the compulsory primary education, free art education is also available. It is legislatively regulated, and available to every child under equal conditions, and its aim is to foster and improve children's intellectual, emotional, social, as well as creative and aesthetic development. Aims of art education focus on experience, knowledge acquisition, skill development and understanding of various aspects of arts and works of art, ultimately aimed at their competent evaluation (Nacionalni kurikulum za umjetničko obrazovanje, 2017). The macroconcepts it is based on focus on knowledge acquisition and development of art skills, understanding the language of art as well as to creative expression on the one hand and, on the other, on students' social and emotional development underlining the fundamental life values such as respect for differences, patience, tolerance and empathy. Within music education, students acquire musical knowledge and skills, make music, promote music through public activity and improve musical culture of the environment the school works in. Additional music education influences their musical as well as overall development, whereby a particular attention should be devoted to the emotional and social component.

Recent research points to the positive aspects of music education and involvement in music as an essential activity in personality formation. Besides the acquisition, development and improvement of music competences, involvement in music also fosters the development of multiple intelligences

"Corresponding author: sabina.vidulin@unipu.hr

(c) (i) 2021 by the authors. This article is an open access article distributed under the terms and conditions of the Creative Commons Attribution (CC BY) license (https://creativecommons.org/licenses/by/4.0/). 
Vidulin, S. \& Kazić, S. (2021). Cognitive-emotional music listening paradigm in professional music education, International Journal of Cognitive Research in Science, Engineering and Education (IJCRSEE), 9(1), 135-145.

(Armstrong, 2006; Gardner, Kornhaber and Wake, 1999). Studies conducted by Gibson, Folley and Park (2009), Hille et al., (2011), Schellenberg (2011), Schelenberg and Mankarious (2012) point to the direct association between involvement in music and improvement of IQ. Association between musical training and cognitive abilities are highlighted by Schellenberg $(2005,2016)$, who also points out that music develops spatial abilities, which is also confirmed by Bilhartz, Bruhn and Olson (1999), Hetland (2000), Rauscher (2002) and Zafranas (2007). Findings of the research by Chan, Ho and Cheung (1998) and Ho, Cheung and Chan (2003) indicate association between music and verbal memory. Schwarzer, Lippke and Luszczynska (2011) notes that music curriculum in schools leads to the improvement of students' visual and aural memory. Gruhn (2002) and Zachopoulou, Tsapakidou and Derri (2004) claim that the beneficial effect of music lessons reflects on children's psychomotor development, while Schellenberg (2016) notes that musical training also influences the development of students' social skills. Musical training also contributes to the development of self-esteem, self-confidence and self-control (Rickard et al., 2013), empathy (Kirchner and Tomasello, 2010; Rabinowitch, Cross and Burnard, 2013), selfconfidence and motivation (Hallam, 2010). It is enhanced by, e.g., students' joint music making, when the attention focuses on the group and when every individual has the opportunity to develop their social and emotional skills, kindness, support, empathy, understanding and respect. Development and improvement of students' abilities, knowledge and skills, learning of values and establishing a critical distance in terms of adopting and permanently bonding to music, culture and art is the goal of music education and, at the same time, the pedagogical and educational function of music classes. In doing so, models and strategies of delivering classes, intensity and duration of education certainly affect the final outcome.

Experience, understanding and evaluation of music by expressing one's own ideas, feelings and thoughts also relate to teaching fundamental life values. Vidulin $(2015,2020)$, and Vidulin, Plavšić and Žauhar (2020) see the direct possibility to achieve this in the area and activity of music listening, which influences children's full development. Music listening arouses senses and reaches affective layers leading to the emotion utterance. The experience of music in its entirety in the atmosphere of relaxation contributes to the group integration, decreases inhibition, improves interpersonal relations, and binds emotion and creativity uniting in the aesthetic.

Although listening is the most natural way to experience and learn music, it is actually a form of work which was the last to be inaugurated in the practice of music teaching. Designing a serious strategy of teaching by means of music listening was allowed only by the technological advancement of the society. Although there is a well-elaborated didactical approach to music listening in school, in the omnipresence of music in the $21^{\text {st }}$ century the teacher is facing new challenges: how to motivate students, increase their attention and contribute to the acceptance of art music.

\section{Ear training: from rational reflection to auditory vividness}

Development of music pedagogy is mostly a result of historical and other circumstances and norms which were generally accepted in a given moment and at a given place, rather than a sequence of logical events or consideration. Some initiatives had a continuity of development regardless of the speed of their dialectic path, while others have been lost forever in the maze of millennium-long expanses (Kazić, 2013). The passage through centuries of efforts and endeavours of music pedagogy and music teaching methods testifies of the multiplicity of procedures, methods and directions, from the elementary ones such as training the children voice and music education by means of children songs, through various didactic, mnemotechnic and graphic aids, to the attempts to foster and raise interest in music in musical and nonmusical way.

During the $19^{\text {th }}$ century, numerous innovations were inaugurated in the area of music teaching. Most authors, regardless of different didactical solutions, always suggest that the auditory way of implementation should precede the visual one, i.e. point to the primarily auditory perception of musical terms before the adoption of graphic marks. The fact that it was only paying lip service is confirmed by the insight into numerous music textbooks and manuals of the time, which primarily and almost as a rule began with music literacy before any other auditory event in the class. Knowledge gained by means of active listening to music models and examples was also a rarity, except when teachers were able to perform something on their own.

Frenchman Wilhem was one of the most influential music pedagogues of the $19^{\text {th }}$ century. He proposes the auditory approach in music education, before mastering music notation and learning theory, i.e. performing. His approach encompasses the identification of elementary sound structures such as notes (pitch level, loudness, source of sound, etc.) and possibly the perception of the size of intervals. 
Wilhem's contemporaries, Swiss journalist and composer Nägeli and Bavarian teacher Pfeiffer were the first to use the term ear training in their textbook Gesangbildungslehre nach Pestalozzis Grundsätsen (1810) which, among other procedures, introduced the musical dictation as a form of work. De Momigny also emphasizes the need for music to be judged by listening, since the auditory perception is more reliable than sheet music (Stefanija, 2008). Although ear training cannot be reduced only to listening training, it is still a significant point of origin, since it implies a kind of guided listening to a melody. The famous composer Schumann also affirmatively spoke of the comprehensive listening and, generally, of the need to listen to a musical piece several times (1849, aphoristic Advice to Young Musicians 39, 47, 50 , $52,67)$, since he believed that a piece cannot be evaluated after a single listening.

The concept of musical upbringing was inaugurated into the system of music education after 1918, and the development of musical abilities was understood as a road toward the permanent musical thinking, with a particular importance being attached to the upbringing of conscious listening with auditory perception. It was believed that the clarity of musical structure while listening can emerge only through conscious experience and sensory ability; thus, refinement of musical ear was achieved by means of intellectual and rational reflection, without expressing the emotional, and even the aesthetic component.

The perception of any sound phenomenon with a rational explanation are the basic principles of Battke's pedagogy and are based on the auditory apperception. The term apperception, in the sense of the perceptively conscious inclusion into the existing content of consciousness, was first used by German philosopher, psychologist and teacher Herbart. Contrary to the ontological viewpoint of Battke, who perceived music as it is, differentiated from the subjective experience, Jaques-Dalcroze is decidedly against such a reduction of perception and response in education to a common level. He believes that musical communication should proceed first through the auditory sense and instinct, and only then through intellect, with rhythmics as the most potent and most vivid element in music (Jacques-Dalcroze, 1921). The framework of Dalcroze method (Eurythmics) provides and develops a series of subtle procedures based on auditory cognition and rhythmics. Music listening proceeds in real time and with the teacher's live performance. The performance is often based on improvised parts performed by the teacher during the class, changing the tempo and melorhythmic structures consequent to the group's responses, which in turn reinforces attention, experience, perception and thinking. Dalcroze's idea is significant because it is a completely original way and perhaps the first time in the history of the group music classes to provide the opportunity for continuous listening to music and only then, on this basis, to proceed with other teaching activities.

Music listening which results in an experience, perception, emotion, analysis, cognition, thinking, aesthetic judgment etc., and which should be the fundamental disposition on the road to the adoption of musical knowledge was not realistically feasible before technology allowed it. During the second half of the $20^{\text {th }}$ century, audio formats began to be used, and music could be listened to every day/the whole day and in any space. Thus Bresgen in his classes relies upon audiotapes and phonograph records (Bresgen, 1960), which opens a completely new approach and new possibilities for teaching music with music in a real time, while music still goes on.

In Alt's concept of music education, in-class music listening has a completely specific and significant place. He believed that technical progress, which allowed the presence of music in every home, poses a potential threat, since such an approach to non-selective listening in a sense make people passive and distant from the artistic in music. Alt recognizes and points to the central task of music education, i.e. to the objective evaluation of a work of art. Alt (1968) believes that music listening makes it possible to learn about different styles and genres, which in turn can lead to a high-quality aesthetic evaluation, which distinguishes the mature listener. In the procedure of in-class music listening, he distinguishes three stages, from passive listening to sound sensations (notes, rhythms, harmonies etc.), which create a picturesque interaction and arouse emotions, through aesthetic listening during the active/guided music listening, to the inspirational listening, when music begins to inspire. Since sound/sonority is a symbol of mental states and music is a need or prerequisite for certain mental events, the prerequisite for inspirational music listening, according to Alt, is a particular degree of its understanding. It is therefore necessary to lead students toward the listening and perception that can objectively evaluate and categorize a multitude of musical impressions in everyday life.

The second half of the $20^{\text {th }}$ century witnessed an evident development of curricula where music obtained its syllabi with objectives, tasks and expected outcomes. They proposed contents which are considered basics of musical culture and the art of music. They also design various methods for its learning and strategies for teaching at different educational levels. The objective of teaching music that primarily pertained to singing by ear (in the didactic, rather than artistic sense), and then to singing by notes aimed at gaining music literacy (Vidulin, Plavšić and Žauhar, 2020) is gradually changing. Music 
Vidulin, S. \& Kazić, S. (2021). Cognitive-emotional music listening paradigm in professional music education, International Journal of Cognitive Research in Science, Engineering and Education (IJCRSEE), 9(1), 135-145.

listening is taking an increasingly significant place. In this respect it is possible to follow both didactical instructions and evaluation of music listening as an approach in education.

\section{Music listening in curricula and didactical manuals in the Western Balkans countries}

In the mid-20 $0^{\text {th }}$ century, music listening gained its place and has been present in music classes in the Western Balkan countries as one of music areas ever since. Overview of the curricula for teaching music in primary schools from 1946 to 2019 (see Vidulin, Plavšić and Zauhar, 2020) reveals that music listening was introduced in music classes in 1948, though it depended on the capacities of schools which, in the post-war period, were not equipped with teaching aids. In the post-war years, records and radio programmes were somewhere listened to in order to allow students to become familiar with music literature, which was a valuable contribution to music listening in schools. Curricula suggested pieces for listening and illustration of particular musical phenomena and concepts, and the attention was focused on getting familiar with music and musicological contents. At present, music listening also primarily focuses on the musical piece and its components, which results in the focus on the cognitive dimension of teaching music.

In one of the first music didactical manuals, Požgaj points out that the teacher can occasionally organize separate classes of music listening, which focus on the perception of the expressive elements of music, and the expression of impressions aimed at forming an aesthetic judgment. For Požgaj, the primary function of music listening is an experience of a work of art, which is always of sentient nature, and therefore the importance is attached to preparation for listening, which will allow stronger impression on listeners. He distinguishes activities of preparation for listening, the experience of musical piece, understanding, expressing impressions, and judging and teaching. Požgaj was certainly one of the first music pedagogues who comprehensively considered all aspects of music teaching, including the establishment of active listening, at the time when radio receivers were still a rarity. In a new edition of Metodika [Didactics], Požgaj brings tape recorders and phonographs in the modern classroom of the time, together with the tape library and records library, radio receiver and television set. In these different circumstances, he believes that music listening is compulsory in every class, at least for a few minutes, and starting from the first grade. He links the sentient experience and mental activity, which he believes to imply the perception and comparison of the elements of musical expression, imagination, musical memory, analytic-synthetic understanding of musical form and forming aesthetic judgment.

Rakijaš distinguishes music listening by means of a mechanical device from listening in one's own, live reproduction, which he considers more valuable in the educational sense. He distinguishes pieces from musical literature according to attributes used to describe music with: fantastic music, dramatic music, emotional music, programme music, etc. According to Rakijaš, music listening fosters the experience, which is the consonance of emotional and mental activity. Plavša, Popović and Debeljak believe that music listening is empirical work. They focus attention on the piece components, aimed at grasping its formal structures, which in turn indicates the complexity of a creative act. In a similar way, Andreé, Baroševčić, Basrak, Krulanović, Kučukalić, Ludvig-Pečar, Požgaj \& Stevković suggest that when listening to music it is important to focus attention on the characteristics of a musical piece, i.e. on its expressive components. Such an approach will allow students to become more familiar with the music they probably do not listen to in their spare time.

For Rojko (1982), work on musicological contents is part of the cognitive process while listening to music. At each repeated listening, instructions and assignments are given and the music is perceived through the prism of analytic-synthetic framework. The importance of giving assignments is also pointed out by Hodžić, who suggests assignments that will allow listening to be careful and active, and children to be focused on the musical contents. The development of students' perceptive abilities of music listening is associated with the entire process of adopting and understanding musical phenomena, so that they can get the opportunity to substantiate their views and opinions on the musical pieces they listened to and shape their aesthetic criteria.

Insight into didactical manuals reveals the tendency to listen to music actively and mostly cognitively. Active listening to a musical piece focused on cognition implies the perception of musical - expressive components and formative structures of a musical piece, and distinguishing musical (theatrical music) types, ways of performance and performing ensembles. Before listening to a musical piece, students are given assignments which motivate them to actively follow, listen to and analyse the music. Perception, auditory identification and distinguishing musical-expressive components are gradually built upon through 
Vidulin, S. \& Kazić, S. (2021). Cognitive-emotional music listening paradigm in professional music education, International Journal of Cognitive Research in Science, Engineering and Education (IJCRSEE), 9(1), 135-145.

education cycles.

Still, it can be observed in the teaching practice that assignments during music listening are identical for every piece, which ultimately does not contribute to its better understanding, and thus acceptance. Since every piece is labelled with a unique musical idiom, it is necessary to insist exactly on its distinctiveness, by which students will recognize it and distinguish it from others, and to emotionally include students in music listening and encourage discussion of emotional experiences and associations that arose due to listening (Vidulin, Plavšić and Zauhar, 2020).

\section{Multimodal concepts of music listening in schools}

Although it primarily focuses on music, music listening can also be viewed in comparison with other musical and extra-musical areas and activities. In this context, we speak of multiple modalities in music teaching. Multimodal approach can spur better achievement and greater motivation (Yu et al., 2010) and allow the creation of more association in experiences (Mayer, 2001).

Novelties in the area of listening to classical music with a multimodal and interdisciplinary approach were introduced by Vidulin (2015; 2017; 2020; Vidulin-Orbanić, 2013). Listening to Music - Music Making (LMM) approach and Stage-English-Music (SEM) concept were designed with the aim of promoting classical music among children and youth, so that they can better understand and accept it. While the LMM approach views music through/with music, SEM is of interdisciplinary character.

LMM approach is based on the immediate connection between music listening and composing and comprises both the cognitive and the emotional context. School-age children's composing is often associated with the knowledge of certain music components which they perceive while listening to musical pieces. The model is specific in that children first get familiar with music through music and then create/ compose it. In doing so, the model makes use only of musical activities. Singing and playing, as the most frequent way of connecting music listening with other areas of music directly affect knowledge and skills and enhance emotional reception of music in children.

Exit from the exclusively musical zone is allowed by the SEM concept, which proposes music listening in combination with other, both musical and extra-musical activities and areas. The multimodal approach influences the culture of listening to classical music, familiarizing with it, understanding and accepting it. Students gain knowledge of musical-style periods, of characteristics of a given piece and its artistic values, they get to know the composer and his life, which affects the cognitive and emotional level of teaching. A particular contribution to the concept is provided by drama education and foreign language (English), which influences students' general culture, developing their musical, drama and language skills. Work with students according to the SEM concept emphasizes students' activities and immediate experience. Listening to the world around them and critical thinking develop students' imagination, influence their behaviour, express views, shape beliefs, identify and express emotions whereby children learn about and discover themselves and the world around them.

As the response to the question as to how regular music classes can become and permanently remain an inciting and creative environment, the cognitive-emotional music listening was introduced (Vidulin, Plavšić and Žauhar, 2020). Multimodal interactive ways of work using multimedia are proposed for completing cognitive and emotional tasks which support the children's holistic development.

Cognitive-emotional music listening starts from the assumption that a music piece will be more permanently adopted if children experience and live through it in multiple modalities, and associate everything with their own viewpoints and beliefs. If a musical piece is brought closer to students in a way appropriate for them, with musical and extra-musical stimuli and with their own activity and expression, it will allow easier and faster learning, better understanding and longer-lasting memory, as well as the emotional reception of the music (Dunn, 2008; 2014; Fung and Gromko, 2001; Johnson, 2013).

Another characteristic of the cognitive-emotional music listening is that the same piece is listened to through three levels during a single class, integrally or fragmentarily, depending on its duration. The first listening is exclusively experiential, spontaneous, focused on the emotional reception of the composition and is not guided by specific questions of cognitive type. The middle level of music listening is cognitively oriented, though the emotional context deepens due to the activity that proceeds in parallel to music listening. It is due to the multimodal listening which is characteristic for the second level of music listening that the emotional context is enhanced since students' activity as well as motivation are at a high level. The final listening is not determined in advanced by questions about musical-expressive components. The piece is listened to as a whole. In this stage, cognitive and emotional aspects are united, with the assumption that the experience can be conditioned by a better knowledge of the piece and its 
Vidulin, S. \& Kazić, S. (2021). Cognitive-emotional music listening paradigm in professional music education, International Journal of Cognitive Research in Science, Engineering and Education (IJCRSEE), 9(1), 135-145.

acceptance. In the final listening, which can be relaxing, students shape their impressions of the piece, express their emotions, show the level of knowledge and analytic skills. Repeated listening to a musical piece or its excerpts, observation and familiarization with the piece from different perspectives, as well as the discussion about the piece and the experience after listening make it possible to better understand the piece and its specifics and - we assume - leads to its acceptance.

Since the essential idea of the described models, concepts and approaches is to promote classical music in schools, it is the school of music that should be the right place where music should be presented by means of listening. Having in mind the structure of classes in schools of music, ear training classes should be the most appropriate for this purpose. However, it is not happening, nor are such possibilities considered. Can reasons for this be found in the overburden of ear training classes with the existing contents, teachers' inertness or something else, are questions that could be specifically answered by research in the area of professional music education.

\section{Music listening in the context of ear training classes}

Music listening by means of reproduction devices as the youngest form of work in music teaching was introduced in the teaching practice of primary general education schools in the subject music education/ training/culture, according to amendments to curricula. Since its introduction, this area was understood as a form of the modernization of music teaching in primary general education schools, and it enriched teachers' work. Learning about the elements of the history of music was less dull if teachers were able to present a couple of audio recordings, and it was exciting for students as well, since at the time many of them did not have the opportunity to listen to music on tapes or records outside the classroom.

In this respect, it can be observed that teaching technology was not used in schools of music until the most recent time, and that therefore ear training classes remained cloaked in traditionalism. We presume that there are several possible reasons for the inertness of music teachers and music pedagogues with respect to modernizing ear training classes by means of introducing new teaching technologies. One of the reasons can certainly involve the very structure of classes, since ear training classes are delivered in a group, as opposed to individual instrument classes. Indeed, from the present perspective, several centuries had to pass from the first organized music teaching in church and guild schools, through classes at conservatories, private lessons, to a form of professional music education such as a structured school of music of the $19^{\text {th }}$ century. Even then, music classes typically implied teaching playing or singing.

Ear training classes were inaugurated as a course in the curriculum of Paris Conservatory in 1795 (Kazić, 2013), and in the $19^{\text {th }}$ century, this model of music teaching was accepted across both France and Europe. Besides major courses, almost all the conservatories of the $19^{\text {th }}$ century had classes in ear training, harmony, counterpoint, sight reading etc. In this respect, ear training classes rounded out their physiognomy relatively fast. Their aims included gaining music literacy and learning elementary theory of music, analytic approach (audible and visual) to interval, triad etc. then sight-singing, rhythm processing, recording musical dictation, possibly learning songs regardless of different didactical viewpoints and solutions. Although the $19^{\text {th }}$ and the $20^{\text {th }}$ century were certainly fraught with a multitude of didactical ideas, procedures, concepts, manuals, textbooks, collections of examples etc., the basic elements of ear training classes have remained almost the same to this day, which is evident in reviewing recent curricula. Besides, some ear training textbooks of the $19^{\text {th }}$ century written by music pedagogues of French tradition, e.g. Panseron, Lavignac, English pedagogues from Curwen's Tonic Sol-fa College, German editions by Hundoegger Tonika-Do-Verlag of the early $20^{\text {th }}$ century can even today be successfully used and are somewhere used in ear training classes.

With respect to the elements of in-class music listening (if an instrument was available), these could be only the elementary melodic or rhythmic structures which were focused on recording musical dictation, audible perception of an interval, melodic and rhythm structures. Therefore, one cannot describe it as a well-conceived cognitive approach. Such music listening served as an aid for doing assignments, rather than being aimed at truly getting closer to the essence of music by means of sensory cognition. No emotion was involved since the assignments of the musical dictation type or analytic identification of given structures were entirely of ontological nature. The previously cited German ontologist Herbart dealt with the issues of form in arts which, according to him, is the entirety of all relations that, for instance, in a musical structure comprises of notes, perhaps rhythm, etc. Its aesthetic value is not subject to a subjective assessment, and therefore to emotion, since aesthetic depends on the relations between content elements which are, in this case, as they are; thus, in their own right. Which relation provides an aesthetic moment, which is good and which is not, is the subject of aesthetics, which in this stage of 
Vidulin, S. \& Kazić, S. (2021). Cognitive-emotional music listening paradigm in professional music education, International Journal of Cognitive Research in Science, Engineering and Education (IJCRSEE), 9(1), 135-145.

education is not necessary. As was already pointed out, it was mostly the ontological moment ear training classes (Kazić, 2019).

Besides the fact that, in the $19^{\text {th }}$ and the first half of the $20^{\text {th }}$ century, ear training was rounded out in terms of the forms of work, in a way, it closed for possible new approaches and solutions. It was the time of the search for didactical procedures and means, a time of great pedagogical ideas, though also of the focus and system, i. e. a road to technicism (Kazić, 2019). The rationalist use of what had already been tested would provide more modest though perhaps the expected outcomes in teaching music, in the sense that the sheet music is sung as soon and as correctly as possible, or that the musical dictation is recorded as soon and as accurately as possible. It is evident in the numerous textbooks and manuals of the time, whose very titles reveal their authors' megalomaniac aspiration to solve such a complex subject matter of ear training exclusively by means of a system of their own exercises (e.g., from French literature, 1600 Exercices Gradués, Cours Complet d'Éducation Musicale, Cours Complet de Solfége, etc.)

At the time when technological conditions were created for listening to musical examples in the class, ear training classes simply did not allow any space for this activity, or for the idea to possibly incorporate music listening in some of the existing procedures and thus increase the supply. Thus, music listening as a potentially valuable form of work remained exclusively in music classes in general education schools.

In a memorable didactical approach, different from previous ones, Bašić (see Letica, 2014) considers music listening as an essential need in the development of aesthetic sensibility. Music listening is syncretically linked to visual expression, which in the most natural way sensitizes and releases emotionality. In this case, music listening activates children's syncretic expression as a form of the unity of motor, speech and musical/musicality elements (Kazić, 2019). The class usually starts with the music of atmosphere or movement, a major or minor mood, as well as possibly with more complex palettes of the offered sound of a musical phenomenon that the teacher performs on the piano. Thus, it is not listening to the integral piece on a phonograph record, though it is also a way to foster attention and experience. The cognitive component is also used as a feedback, since monitoring children's responses to the musical woof provides knowledge of their actual abilities, which makes it possible to use children's dispositions in the further development of their artistic, i.e. aesthetic upbringing.

Didactical manuals for ear training (Grgošević, Kazić, Radičeva, Rojko, Vasiljević) do not consider listening to music examples by means of reproduction devices in any segment. Kazić $(2013,2019)$ proposes the audio recording as a possibility for work on musical dictations; however, in these instances attention is focused only on the assignment rather than on the well-conceived listening and musical experience of the emotional component of the piece. Neither do the manuals such as 222, 555 izabranih tema za solfeggio [222, 555 selected themes for ear training] (Marković) or even 999 glazbenih tema iz glazbene literature za solfeggio [999 musical themes from musical literature for ear training] (Golčić) open the way for gradual understanding and experiencing a work of art since these are short themes taken out of the context of a whole, or short excerpts from great orchestral forms that are notated monophonic. Such examples can certainly be used for sight singing or playing, or for dictations, but - at this level - they can hardly be experienced and viewed in the context of the entirety of a musical piece. Although Popovic suggests that, after singing an example from art music literature in his textbook students hear the entire piece from a phonograph record, the appropriateness of such an approach is debatable. Students are unlikely to find their way and recognize the previously sung theme in the entire sound by listening to the performance of a symphony orchestra.

Certainly, the context of ear training classes does not recognize integral or partial listening to a musical piece as a potential didactical procedure or a possibility to incorporate it as such in another, already existing procedure. This could perhaps confirm the significance of the emotional component in ear training classes, since all modern approaches unambiguously point to the need for synergy between cognitive and emotional in art teaching.

\section{Prospects of cognitive-emotional music listening in ear training classes in the primary music school}

Cognitive-emotional music listening has certainly opened the possibility to incorporate this way of listening in other areas, such as ear training. Since the listening is aimed at shaping students' culturalartistic worldview and at contributing to their aesthetic upbringing, its task is to develop and improve students' musical competences, and the objective is to experience, understand and accept art music, the described postulates can be mapped to the area of ear training as well. The possibility of achieving 
the goal is even greater in the music school, since classical music is the focus of work in students' music education, and the number of hours is greater than that of music classes in the general education school. Focus on the cognitive and emotional dimension of music and learning, repeated listening, and multimodal and interdisciplinary approach to a musical piece can be achieved in ear training classes, where it is also possible to foster a humanistic paradigm that leads to students' holistic upbringing and education.

Repeated listening in ear training classes, as well as in music classes in the general school proceeds in stages, and we therefore recognize further similarities in cognitive-emotional music listening between different subjects. The initial listening is emotional and supports the experience of the whole without announcements and stimuli. It is spontaneous and is followed by a discussion about impressions. The middle listening is of cognitive and emotional types. Students are motivated and guided by musical and extra-musical stimuli to experience a musical piece more intensely and get familiar with it. The listening is multimodal, and students participate actively. The final listening, which also sums up the subject matter, is of cognitive-emotional character and spontaneous. The teacher probes the overall impression and encourages various ways of students' expression. Besides learning about the musical-historical context of the emergence of the piece at a given time and space, composing procedure and theoretical and harmonic features of the piece, students develop their musical/musicality thinking, are encouraged to think critically and evaluate the music, as well as to discover and self-realize their own selves.

Together with the described features of the approach, which can be used when delivering teaching units in both general and music school, attention should be paid to the fact that the cognitive approach to listening in the music school is more complex due to the scope of musical knowledge and skills that students should gain in ear training classes. It is for this reason that preparations for work in ear training classes in the primary music school should be based on laws and contents of ear training, although they will be dealt with in a somewhat different way by means of cognitive-emotional listening. When developing the cognitive-emotional listening lesson plans, it is important for teachers to be guided by criteria such as appropriateness for the students' age, as well as the compliance with the curriculum, and to pay a particular attention to studying the musical piece and discovering the message it brings. In this way, the musical piece will become and remain impressive for students and will influence their development, both as musicians and as humane and emphatic persons.

Since research findings of a comprehensive study on the cognitive-emotional music listening have been published in several stages in papers by Vidulin, Plavšić, and Žauhar $(2019,2020)$, Vidulin and Plavšić (2020), and Vidulin (2020), advantages of the cognitive-emotional approach compared to the standard approach to music listening have been confirmed. In the multimodal approach supported by musical and extra-musical activities, increased interaction and active participation, students were more focused on the musical piece and expressed the desire to listen to it again. Their cognitive and emotional experience helped them to generate a larger number of responses of a broader spectrum which pertained to the cognitive elements, e.g. recognition of musical components, and to emotional elements, e.g. associations to the piece and identification of emotions, as well as the experience of the music. The findings also indicate that the teacher's guidance and the level of students' (inter)activity during the class are decisive for their experience of music listening.

Although the value of the cognitive-emotional music listening has been recognized and proven by research in the primary general education school, many questions remain open. In this respect, answers are expected that will improve the professional music education and provide guidelines related to the role, function and significance of music listening in ear training classes and that pertain to musical dictation, sight-singing, mastering melodic and rhythmic structures, and theory of music. Besides, it will be important to determine guidelines pertaining to the detection of the psychological processes that support the cognitive-emotional music listening in ear training classes, skills and competences allowed by the approach, way of delivering classes and expected outcomes.

Research of the cognitive-emotional music listening in ear training classes will be guided by research findings pertaining to the primary music school, though respecting the specifics of the course in ear training. It is important to find the optimum multimodal interactive methods that will help students to understand, analyse, try out, experience, memorize and accept the piece they listen to, as well as to discover their own selves, enrich their personal and emotional experience.

\section{Conclusions}

Tracking the historical course of didactical initiatives in the area of ear training reveals the tendency to use primarily the audible perception of musical concepts; however, the practical implementation was 
a rarity until the emergence of technical devices. Conscious music listening with the audible perception found its place in the mid- $20^{\text {th }}$ century and has, to this day, mostly been based on intellectual and rational reflections, without expressing the emotional and aesthetic component. Although there are exceptions which point to the association between music listening and rhythmical movement or visual-art expression, and although some music pedagogues also propose the continuous listening, the active and guided music listening and expressing impressions and the emotional experience, focusing attention on the expressive musical components still prevails. The emotional approach to music listening that can be detected in the history of ear training as a formulation or aspiration has not been associated with listening to an actual musical piece, or the listening was linked to a specific assignment.

If music listening is viewed as a possibility that results in an experience, perception, emotion, analysis, cognition, opinion, aesthetic judgment etc., it is apparent that it requires a change in the listening strategy, as well as in its goal. The cognitive characteristics are still important part of learning about music, and therefore giving assignments before music listening can still be considered a good didactical procedure, which motivates students to actively follow, listen and analyse music. However, besides the well-conceived assignments that lead to the cognitive dimension of music listening, it is important to emotionally involve students in music listening and to encourage discussion of emotional experiences, states and associations resulting from the listening.

Though primarily music-oriented, music listening in ear training classes can also be observed in its relationship with other musical and extra-musical areas and activities, in the multimodal and interdisciplinary way. Classical music, which is the foundation of work in the school of music, is experienced and studied mostly by means of musical activities: by singing, playing, listening, all of which influence the development of students' musical knowledge and skills. However, the cognitive-emotional listening deepens this development. Music listening can be incorporated in some of the already existing procedures, music can be listened to repeatedly, integrally or partially, and the expected outcome will encompass both learning about musical phenomena, i.e. better understanding of music, and experiencing and identifying the emotions transferred by the music and states that the listener is in.

Developing lesson plans based on the cognitive-emotional listening, its research in practice and testing its success, all aimed at correcting the objective and tasks of music listening in the music school could be a polygon for modernizing ear training classes. Repeated listening to a musical piece or its excerpt, observing and learning about the piece from different perspectives and discussion of the piece and experience make it possible to better understand the piece and its specifics. A shift away from musical literacy, sight-singing and learning the theory of music, together with musical dictation, audible perception of intervals, chords or a rhythmic structure, which are the end in themselves, toward the cognitiveemotional listening will allow students' development both as musicians and as humane members of social community. By making music, learning, developing skills and expressing their personal viewpoints, beliefs and emotions and accepting others' positions, they will get to know and learn to respect both themselves and others.

\section{Conflict of interests}

The authors declare no conflict of interest.

\section{References}

Alt, M. (1968). Didaktik der Musik: Orientierung am Kunstwerk [Didactics of Music: Orientation towards the artwork]. Düsseldorf: Pädagogischer Verlag Schwann.

Armstrong, Th. (2006). Višestruke inteligencije u razredu [Multiple intelligences in the classroom]. Zagreb: Educa.

Bilhartz, T. D., Bruhn, R. A., \& Olson, J. E. (1999). The effect of early music training on child cognitive development. Journal of Applied Developmental Psychology, 20(4), 615-636. https://doi.org/10.1016/S0193-3973(99)00033-7

Bresgen, C. (1960). Die Improvisation [Improvisation]. Heidelberg: Quelle \& Meyer.

Chan, A. S., Ho, Y. C., \& Cheung, M. C. (1998). Music training improves verbal memory. Nature, 396(6707), 128-128. https:// doi.org/10.1038/24075

Dunn, R. E. (2008). The effect of auditory, visual, or kinesthetic perceptual strengths on music listening. Contributions to Music Education, 35, 47-78. Retrieved from http://www.jstor.org/stable/24127162

Dunn, R. E. (2014). Life music as a beginning point: Connecting with the intuitive listener. The Musical Experience: Rethinking music teaching and learning Online: Oxford Scholarship Online. Retrieved from https://static1.squarespace.com/ static/561b5fd6e4b0beb4167429b1/t/561ba97be4b0a09ae30575de/1444653435226/Connecting+with+the+Intuitive+ Listener.pdf

Fung, C. V., \& Gromko, J. E. (2001). Effects of active versus passive listening on the quality of children's invented notations and preferences for two pieces from an unfamiliar culture. Psychology of Music, 29(2), 128-138. https://doi. org/10.1177/0305735601292003 
Vidulin, S. \& Kazić, S. (2021). Cognitive-emotional music listening paradigm in professional music education, International Journal of Cognitive Research in Science, Engineering and Education (IJCRSEE), 9(1), 135-145.

Gardner, H., Kornhaber, M. L., \& Wake, W. K. (1999). Inteligencija: različita gledišta [Intelligence: different points of view]. Jastrebarsko: Naklada Slap.

Gibson, C., Folley, B. S., \& Park, S. (2009). Enhanced divergent thinking and creativity in musicians: A behavioral and nearinfrared spectroscopy study. Brain and Cognition, 69(1), 162-169. https://doi.org/10.1016/j.bandc.2008.07.009

Gruhn, W. (2002). Phases and stages in early music learning. A longitudinal study on the development of young children's musical potential. Music Education Research, 4(1), 51-71. https://doi.org/10.1080/14613800220119778

Hallam, S. (2010). The power of music: Its impact on the intellectual, social and personal development of children and young people. International Journal of Music Education, 28(3), 269-289. https://doi.org/10.1177/0255761410370658

Hetland, L. (2000). Learning to make music enhances spatial reasoning. Journal of Aesthetic Education, 34(3/4), $179-238$. https://doi.org/10.2307/3333643

Hille, K., Gust, L., Bitz, U., \& Kammer, T. (2011). Associations between music education, intelligence, and spelling ability in elementary school. Advances in Cognitive Psychology, 7, 1-6. https://doi.org/10.2478/v10053-008-0082-4

Ho, Y-C, Cheung, M-C., \& Chan, A. S. (2003). Music training improves verbal but not visual memory: Cross-sectional and longitudinal explorations in children. Neuropsychology, 17(3), 439-450. https://doi.org/10.1037/0894-4105.17.3.439

Jacques-Dalcroze, E. (1921). Rhythm, music and education. New York: GP Putnam's Sons.

Johnson, D. (2013). Creating meaningful music listening experiences with active music making. Musicworks: Journal of the Australian Council of Orff Schulwerk, 18, 49-56. https://doi.org/10.3316/informit.594189376467615

Kazić, S. (2013). Solfeggio: historija i praksa [Ear training: History and practice]. Sarajevo: Muzička akademija, Muzikološko društvo FBIH.

Kazić, S. (2019). Muzička improvizacija u edukaciji: historija i praksa [Musical improvisation in education: History and practice]. Sarajevo: Muzička akademija u Sarajevu.

Kirschner, S., \& Tomasello, M. (2010). Joint music making promotes prosocial behavior in 4-year-old children. Evolution and Human Behavior, 31(5), 354-364. https://doi.org/10.1016/j.evolhumbehav.2010.04.004

Letica, M. (Ed.) (2014). Vjerujem svakom djetetu - tekstovi iz ostavštine Elly Bašić [I trust every child - texts from the legacy of Elly Bašić]. Zagreb: GU Elly Bašić.

Mayer, R. E. (2001). Multimedia learning. New York: Cambridge University Press.

Nacionalni kurikulum za umjetničko obrazovanje [National Curriculum for Art Education] (2017). Zagreb: Ministarstvo znanosti i obrazovanja. Retrieved from https://mzo.gov.hr/istaknute-teme/odgoj-i-obrazovanje/nacionalni-kurikulum/nacionalnikurikulumi/531

Rabinowitch, T-C., Cross, I., \& Burnard, P. (2013). Long-term musical group interaction has a positive influence on empathy in children. Psychology of Music, 41(4), 484-498. https://doi.org/10.1177/0305735612440609

Rauscher, F. H. (2002). Mozart and the mind: Factual and fictional effects of musical enrichment. In J. Aronson (Ed.), Improving academic achievement: Impact of psychological factors on education (pp. 269-278). New York: Academic Press. https://doi.org/10.1016/B978-012064455-1/50016-6

Rickard, N. S., Appelman, P., James, R., Murphy, F., Gill, A., \& Bambrick, C. (2013). Orchestrating life skills: The effect of increased school-based music classes on children's social competence and self-esteem. International Journal of Music Education, 31(3), 292-309. https://doi.org/10.1177/0255761411434824

Rojko, P. (1982). Psihološke osnove intonacije i ritma. [Psychological bases of intonation and rhythm]. Zagreb: Muzička akademija - Croatia concert. Retrieved from https://bib.irb.hr/datoteka/567762.P._Rojko_Psiholoke_osnove_ intonacije_i_ritma.pdf

Schellenberg, E. G. (2005). Music and cognitive abilities. Current Directions in Psychological Science, 14(6), 317-320. https:// doi.org/10.1111/j.0963-7214.2005.00389.x

Schellenberg, E. G. (2011). Examining the association between music lessons and intelligence. British Journal of Psychology, 102(3), 283-302. https://doi.org/10.1111/j.2044-8295.2010.02000.x

Schellenberg, E. G. (2016). Music training and nonmusical abilities. In S. Hallam, I. Cross, \& M. Thaut (Eds.), Oxford library of psychology. The Oxford handbook of music psychology (pp. 415-429). Oxford University Press

Schellenberg, E. G., \& Mankarious, M. (2012). Music training and emotion comprehension in childhood. Emotion, 12(5), 887891. https://doi.org/10.1037/a0027971

Schumann, R. (1849). Album für die Jugend [Album for young people], Op.68. Hamburg: Schuberth.

Schwarzer, R., Lippke, S., \& Luszczynska, A. (2011). Mechanisms of health behaviour change in persons with chronic illness or disability: The Health Action Process Approach (HAPA). Rehabilitation Psychology, 56(3), 161-170. https://doi. org/10.1037/a0024509

Stefanija, L. (2008). Metode analize glazbe - Povijesno-teorijski ocrt [Methods of music analysis - Historical-theoretical outline]. Zagreb: Hrvatsko muzikološko društvo.

Vidulin, S. (2015). Korelacija umjetnosti i jezika u svrhu razvoja učenikova znanja i umijeća [Correlation of art and language for the purpose of developing students' knowledge and skills]. In M. Petrović (Ed.), Sociološki aspekt pedagogije i izvođaštva u scenskim umetnostima (pp. 189-200). Beograd: Fakultet muzičke umetnosti.

Vidulin, S. (2017). The "Listening to and Making Music" approach in the function of improving musical understanding. Glasbenopedagoški zbornik Akademije za glasbo v Ljubljani/The Journal of Music Education of the Academy of Music in Ljubljana, 145-162. Retrieved from https://bib.irb.hr/datoteka/932300.Vidulin_Listening_to_and_Music_Making_ Approach.pdf

Vidulin, S. (2020). Music teaching in regular class and extracurricular music activities in Croatia: State and perspectives. Hungarian Educational Research Journal, 10(2), 143-154. https://doi.org/10.1556/063.2020.00015

Vidulin-Orbanić, S. (2013). Glazbeno stvaralaštvo: teorijski i praktični prinos izvannastavnim glazbenim aktivnostima [Musical creativity: theoretical and practical contribution to extracurricular musical activities]. Pula: Udruga za promicanje kvalitete i poticanje izvrsnosti u odgoju i obrazovanju „SEM“.

Vidulin, S., \& Plavšić, M. (2020). Contribution of cognitive-emotional approach to music listening on students' cognitive and emotional experience. Musicological Annual, 56(1), 225-241. https://doi.org/10.4312/mz.56.1.225-241

Vidulin, S., Plavšić, M. \& Žauhar, V. (2019). Usporedba spoznajnog i emocionalnog aspekta slušanja glazbe u glazbenopedagoškom kontekstu osnovne škole [A comparison between the cognitive and emotional aspects of music listening 
in the context of primary school music teaching]. Metodički ogledi: časopis za filozofiju odgoja, 26(2), 9-32. https://doi. org/10.21464/mo.26.2.4

Vidulin, S., Plavšić , M., \& Žauhar, V. (2020). Spoznajno-emocionalno slušanje glazbe u školi [Cognitive-emotional listening to music in school]. Pula. Sveučilište Jurja Dobrile u Puli, Rijeka: Filozofski fakultet.

Zachopoulou, E., Tsapakidou, A., \& Derri, V. (2004). The effects of a developmentally appropriate music and movement program on motor performance. Early Childhood Research Quarterly, 19(4), 631-642. http://dx.doi.org/10.1016/j. ecresq.2004.10.005

Zafranas, N. (2007). Piano keyboard training and the spatial-temporal development of young children attending kindergarten classes in Greece. Early Child Development and Care, 174(2), 199-211. https://doi.org/10.1080/0300443032000153 534

Yu, P. T., Lai, Y. S., Tsai, H. H., \& Chang, Y. H. (2010). Using a multimodal learning system to support music instruction. Journal of Educational Technology \& Society, 13(3), 151-162. Retrieved from http://www.jstor.org/stable/jeductechsoci.13.3.151 
Vidulin, S. \& Kazić, S. (2021). Cognitive-emotional music listening paradigm in professional music education, International Journal of Cognitive Research in Science, Engineering and Education (IJCRSEE), 9(1), 135-145. 